\title{
Use of Underground Constructions Enhanced with Evaporative Cooling to Improve Indoor Built Environment in Hot Climate
}

\author{
Mamdooh Alwetaishi
}

check for

updates

Citation: Alwetaishi, M. Use of Underground Constructions Enhanced with Evaporative Cooling to Improve Indoor Built Environment in Hot Climate. Buildings 2021, 11, 573. https://doi.org/10.3390/buildings 11120573

Academic Editors: Chyi Lin Lee, Samad M. E. Sepasgozar and Lan Ding

Received: 30 October 2021

Accepted: 16 November 2021

Published: 23 November 2021

Publisher's Note: MDPI stays neutral with regard to jurisdictional claims in published maps and institutional affiliations.

Copyright: (c) 2021 by the author Licensee MDPI, Basel, Switzerland. This article is an open access article distributed under the terms and conditions of the Creative Commons Attribution (CC BY) license (https:/ / creativecommons.org/licenses/by/ $4.0 /)$.
Department of Civil Engineering, College of Engineering, Taif University, P.O. Box 11099, Taif 21944, Saudi Arabia; m.alwetaishi@tu.edu.sa

\begin{abstract}
Underground constructions (UGCs) have been used globally to accommodate a wide range of building usage, such as offices and shopping malls. Most of these constructions suffer from a lack of natural ventilation as well as daylight, as they are completely built under the surface of the earth. This has caused many issues related to discomfort, impacting the activity and the productivity of users. This study aimed to analyse the effect of the use of UGCs in hot regions, enhanced by partly elevated external walls which reach aboveground to ensure natural ventilation and daylight, with relatively small amounts of glazing to minimise the influence of solar heat gain. The study used a real built underground room with field measurements for indoor temperature and relative humidity. Moreover, the study used the computer tool EDSL TAS to simulate the performance of the model throughout the year after a field validation. It was concluded that the use of UGCs in hot climates should be encouraged as natural ventilation and daylight can decrease temperatures by $3{ }^{\circ} \mathrm{C}$ in summer, and the utilisation of evaporative cooling can cool the indoor environment by nearly $12^{\circ} \mathrm{C}$. Furthermore, heat transfer was highly affected by the external environment. It was found that the amount of heat transfer doubled in comparison between under and aboveground constructions. The use of small windows for ventilation caused high humidity, even in hot regions, during summer.
\end{abstract}

Keywords: underground buildings; hot regions; natural ventilation; daylight; evaporative cooling

\section{Introduction}

\subsection{Background}

Evaporative cooling is an important technique used in the Middle East to cool outdoor conditions in extremely hot climates. Figure 1A shows one of the traditional evaporative cooling strategies using wind catchers. Earth's shelters are an obtainable technology developed from methods used since ancient times to counteract the extremes of outdoor climatic conditions globally $[1,2]$. They could be used for different reasons, such as residences for people, or soil for growing food [3]. The temperature of the subsurface is commonly lower than that over ground in the summer and higher in the winter, due to its thermal mass advantages. Worldwide, there has been a noteworthy increase in the number of underground constructions (UGCs). For example, in railways, such as the Antwerpen central railway station in Belgium; hospitals, such as the Ceppo hospital of Pistoia in Italy; and shopping centres, such as the Gangnam station underground shopping mall in South Korea. This evolution is connected to the expansion of the urban scale of cities and towns [4]. Consequently, cities such as Riyadh need UGC, where the case study of the UG room has been constructed, to meet the rapidly increasing demand [5]. 


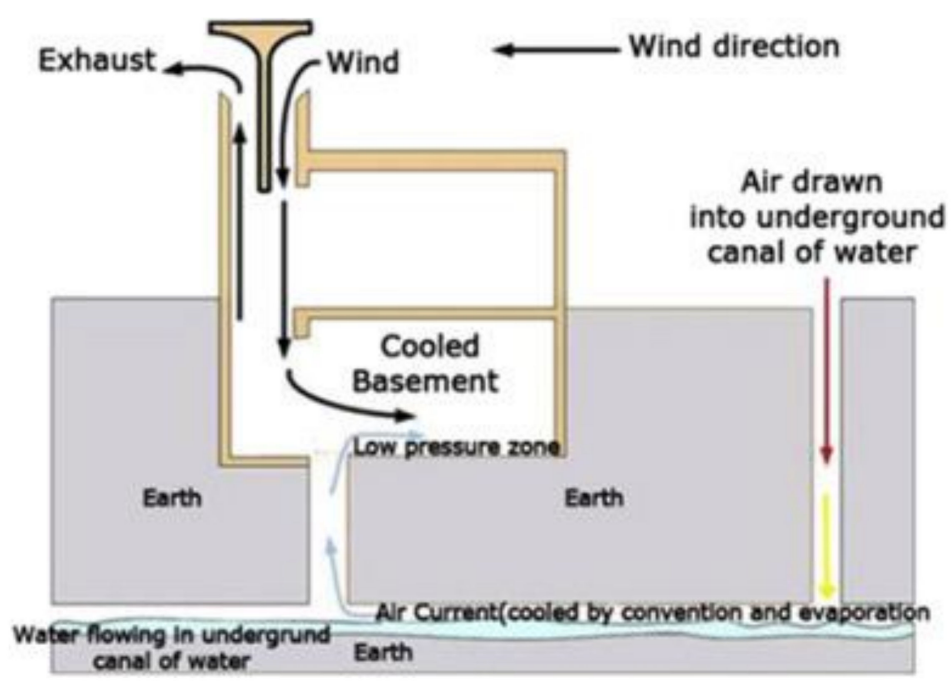

(A)

(B)

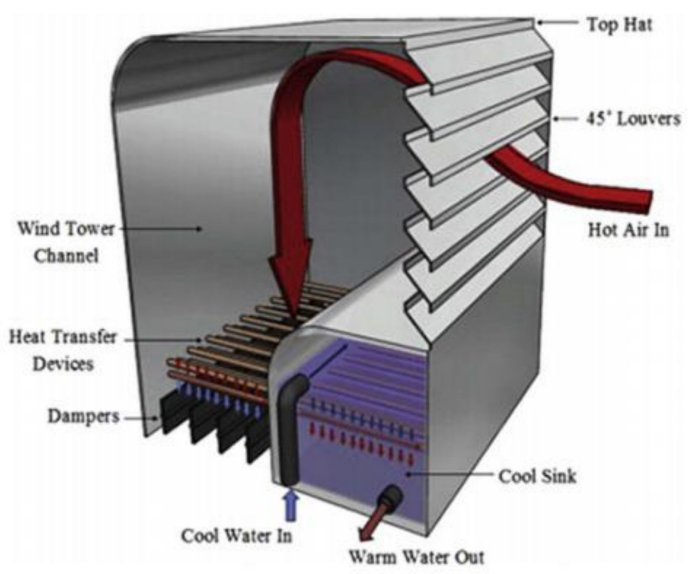

(C)

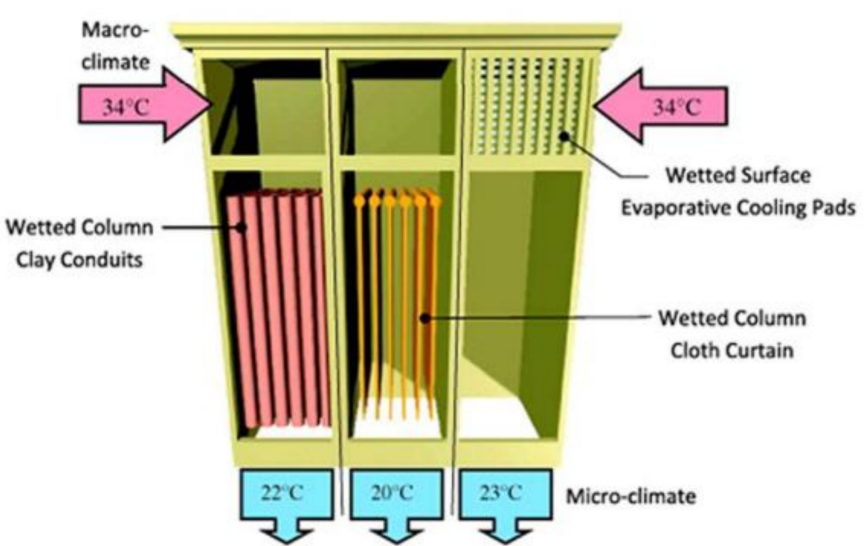

Figure 1. Old and traditional wind catcher in the Middle East (A), modern systems of wind catchers where (B) is used in an operating heat transfer system, and (C) is a thermal operation integrated with wetted columns. Reprinted from Ref. [6].

More than $30 \%$ of the available land mass on Earth is in hot regions, while only $12 \%$ is in regions with a temperate climate. This makes it important to consider hot climatic regions. Energy consumption from buildings is higher than that from any other comparable sector [7]. This shows the importance of utilising UGCs in the steering of building energy consumption. According to Shi [4], the use of UGCs can save approximately $23 \%$ of energy. Furthermore, the utilisation of UGC will aid in isolating buildings from outdoor noise [2]. One of the impediments of UGC is the shortage of indoor environmental quality (IEQ), yet it is fundamental to devise approaches to maintain comfortable indoor environments that meet the international standards of IEQ [8]. Recent research has indicated that an acceptable thermal comfort level is achievable with less use of energy by UGCs [9].

\subsection{Literature Review}

\subsubsection{Evaporative Cooling}

In hot regions, several studies have highlighted different methods to improve the level of thermal comfort as well as energy consumption in UG spaces. For instance, Rabani [10] presented the utilisation of water spraying in UGCs, which has the ability to lower the temperature of indoor environments by $7-13{ }^{\circ} \mathrm{C}$. This is comparable to the research of Alwetaishi [11], which explored the influence of water spraying at Mashrabiya in an historical building in a hot region; the work revealed that it is possible to lower the indoor 
temperature by $4{ }^{\circ} \mathrm{C}$ during summer in the city of Taif. This potential is larger in a region with a hot and arid climate. Although a region with a hot and humid climate is considered a hot region, the high level of humidity makes it difficult for the evaporative cooling system to work effectively [12]. In [13], which includes a case study from the city of Jeddah in Saudi Arabia, the analysed region is hot and humid. The study included an experimental field investigation for EC techniques with Mashrabiya. The work highlighted the difficulties in achieving the comfort level midday due to the high level of heat combined with high humidity. The system works more efficiently in hot and dry regions. In the UAE, Trepci [14] investigated the built context impact as passive cooling in the hot climate. The researcher introduced different aspects to control passive cooling at the level of urban design, such as height, distance, and orientation, which can contribute to a $26 \%$ increase in cooling energy. In the composite climate of India, $[15,16]$ highlighted the influence of EV on thermal comfort. The researchers reported the strong connection between EV and thermal comfort. Using the Griffith method, it was found that comfort satisfaction in India is higher than the suggested values of ASHRAE 55 and ISO 7730, with an average of $28.8^{\circ} \mathrm{C}$. Evaporative cooling is not restricted to a certain method, it has many applications. In a study of Sotelo-Salas [17], which is located in the hot climate of Mexico, the researchers used spray evaporative cooling in an opaque skin façade for cooling, using CFD. The evaporative cooling (EC) technique is not restricted to hot regions; it is also used in other climates during summer. In the work of Kowalski [18], which was carried out in Poland, EC systems were used in industrial buildings. The author reported that an EC system has a strong potential for energy saving under the climatic conditions of Poland.

In some countries in the Middle East, wind catchers are used along with evaporative cooling systems. In Kuwait, in [19], the researchers explored the utilisation of wind catchers with EC to improve indoor air quality and energy efficiency. It was reported that the system reduced energy consumption by $52 \%$ and improved thermal comfort by $76 \%-100 \%$ with a free running air conditioning operation. In the context of Tunis, in $[20,21]$, the researchers highlighted the possibility of reducing the indoor air temperature by an average of approximately $15{ }^{\circ} \mathrm{C}$ and raising the relative humidity by $54 \%$. However, the effect of the system on energy consumption was not clear in the research.

\subsubsection{Underground Construction Studies}

Studies on UGCs are abundant globally [22-24]. Even though there are numerous research publications on the topic of UGCs, such as [25-31], very few have looked at residential buildings. This shows the significance of this research. In a study carried out by Shan [32] in Singapore, the author reported that thermal comfort was developed, as well as a notable resistance to outdoor noise. In contrast, there are some disadvantages of UGCs, such as lack of daylight, cost of construction, and psychological issues.

UGCs come in various shapes, such as atria, elevation plans, and Bermed plans [33]. Irrespective of the local climatic condition, there are leading elements which influence the behaviour of UGCs, such as design, depth of UGCs, utilisation of natural ventilation, soil property, conductivity of thermal mass, and elevation above sea level [34-36]. As a result, natural ventilation is very crucial in UGCs as it is linked to a high level of moisture [37]. UGCs have some barriers, as mentioned before, such as isolation from aboveground and lack of daylight. This might be ameliorated by the use of plants as suggested by Kim [38]; Kim's work indicated a positive perception with the existence of plants in the building. Moreover, the work suggested using artificial windows, which has been found to be beneficial in underground indoor spaces.

\subsubsection{Thermal Mass and Its Influence on Underground Constructions}

The use of thermal mass (TM) can be classified into two major combinations: internal insulation (for instance, the existence of furniture) and external insulation (such as walls, roof, and floor) [39]. The use of thermal mass can be efficacious in the constriction of energy use and maintenance of comfort level [40-44]. In fact, thermal comfort might be 
considered the most appropriate aspect in hot regions [45], or during a warm summer in countries with milder climates [40,46,47]. Recently, Kumar, in [48], reported that the use of TM is beneficial not only in regions with hot climate but also in locations of composite climatic conditions, such as India. A comparison between an historical building which was constructed using stone building material, and another that was constructed using modern building materials such as bricks was carried out by Yousef [49] in the hot region of Egypt. The study revealed that the technique used in this heritage building helped to reduce the temperature of the indoor environment by approximately $1.4{ }^{\circ} \mathrm{C}$. Furthermore, a wide range of research has been conducted on historical buildings $[50,51]$.

TM is ultimately connected to thermal comfort. Based on the work conducted by Kumar [52], between $40 \%$ and $98 \%$ of thermal discomfort perception can be avoided with the utilisation of TM in buildings. However, some of the published research is against this. These scholars are of the opinion that the use of TM has no effect on energy use but may help in ameliorating the comfort level [53].

\subsection{Context of Extreme Climate of Al Dwadimi City in Saudi Arabia}

The town of Al-Dawadmi is located in the heart of Saudi Arabia's desert with the coordinates of $24^{\circ} 50^{\prime} \mathrm{N} 44^{\circ} 39^{\prime}$ E (Figure 2). It is located in the heart of Saudi Arabia, approximately $300 \mathrm{~km}$ west of the capital of Saudi Arabia, Riyadh. It has a desert climate with a very hot summer and cold winter. The unique feature of this town is that it is elevated roughly $1000 \mathrm{~m}$ above sea level, which leads to a very cold climate in winter. The town is known for its historical tourist destination Ash Shu'ara heritage village.

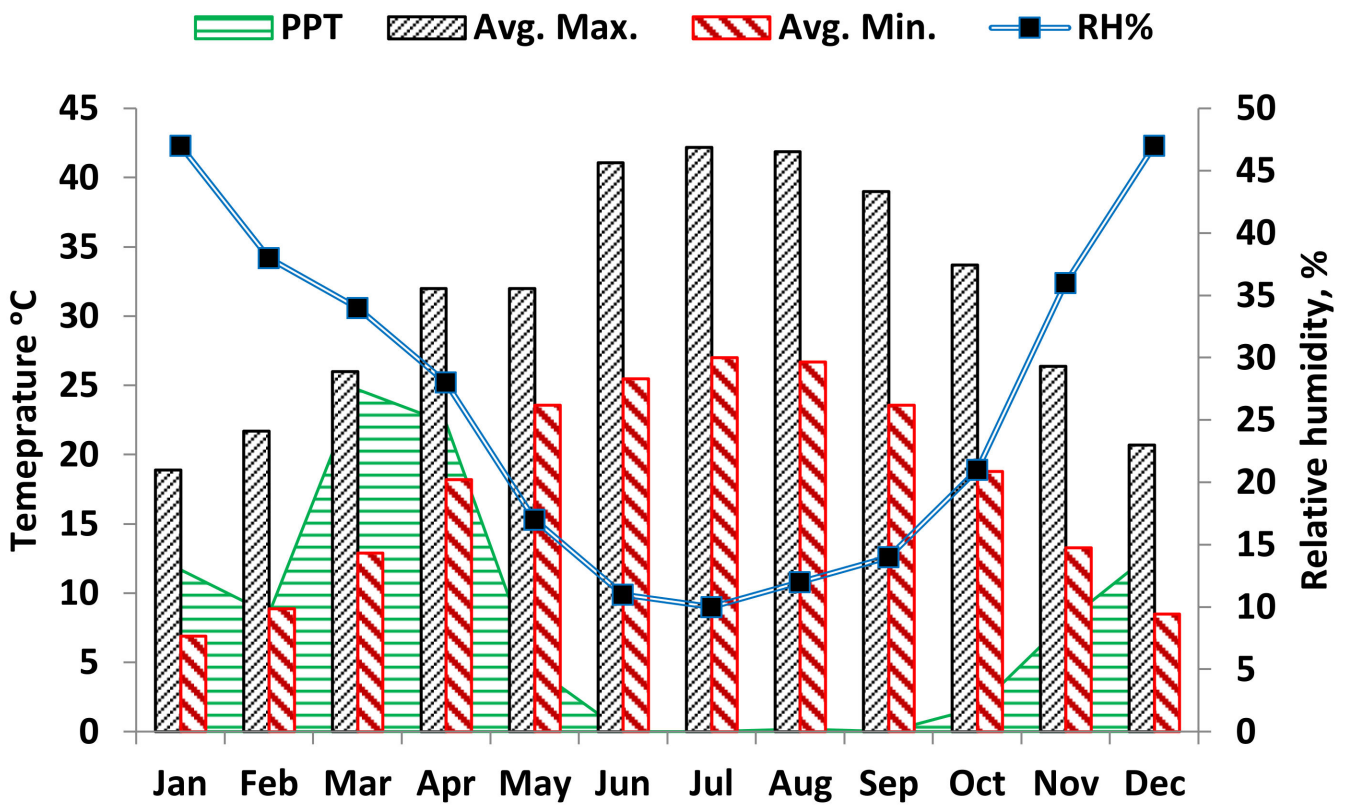

Figure 2. Weather data of Al-Dwadimi town Reprinted from Ref. [54]. PPT denotes precipitation.

\subsection{Aim and Objectives of Study}

The aim of this study was to investigate the effects of underground building construction with a new design to allow natural ventilation and daylight combined with an evaporative cooling system to improve comfort and energy efficiency. This aim was achieved through different objectives. A literature review on UGCs, TM influence, and evaporative cooling was conducted (Figure 3 shows a schematic representation of the evaporative cooling system). 


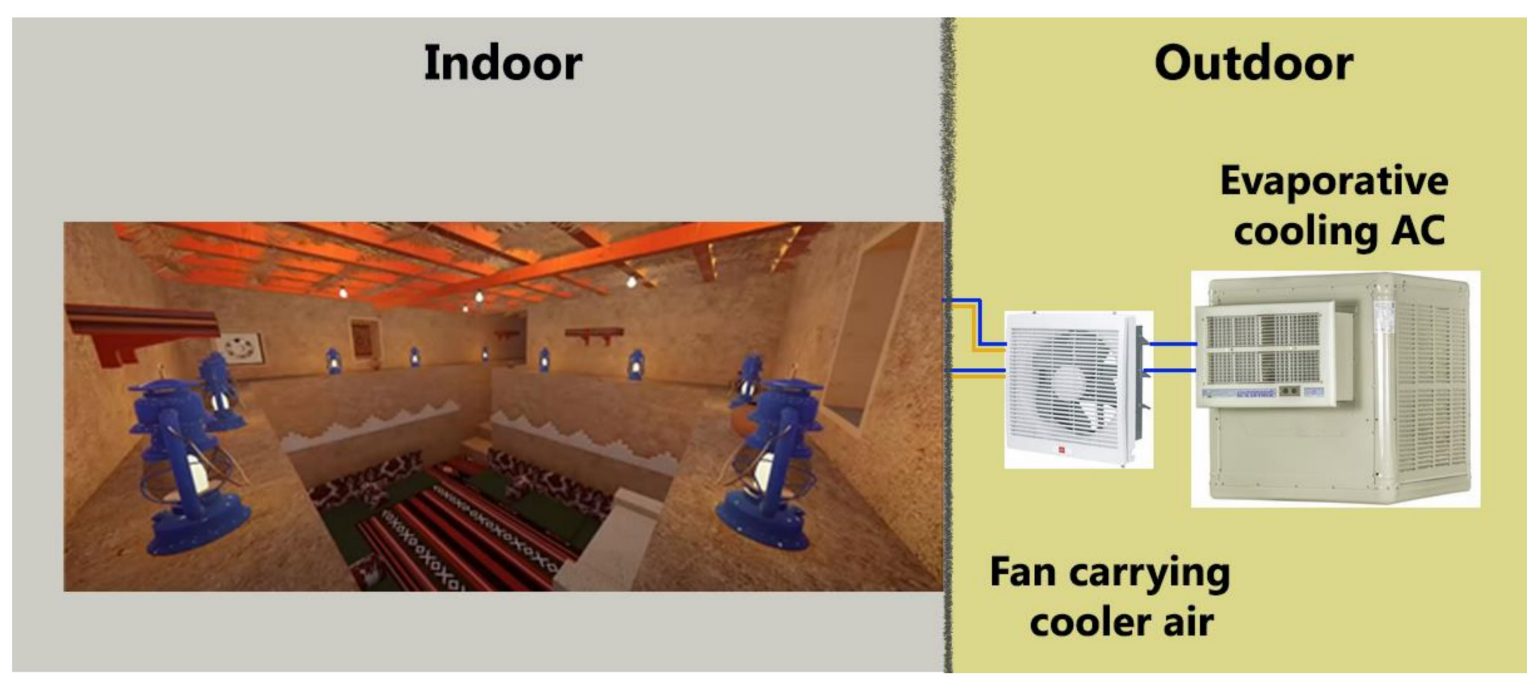

Figure 3. System design of evaporative cooling unit.

\subsection{Novelty and Significance of Study}

Thermal control and comfort are very crucial in regions with extreme climatic conditions. The climate might be extremely hot or extremely cold such as that in Riyadh and Stockholm, respectively. Such locations require more environmental architectural design enriched with appropriate building materials to reflect the need of the local climate. The element of UGC is a traditional approach to control the indoor built environment in the Middle East, as it suffers from extreme temperatures.

Although there has been abundant research on UGCs, such as [25-31], only little of it features new designs to allow both natural ventilation and daylight. This shows the significance of this study to contribute to the existing knowledge, particularly in the context of the hot climates of Gulf countries, where there is a very little research contribution. In fact, based on the extensive research on the topic thus far, there has been no study conducted in the region of the Middle East where there is a field constructed underground space with an evaporated air conditioning system. This reflects the novelty of the study which can contribute in different ways to the existing knowledge. The use of a field construction added enhancement to the methodology is the novelty of the study. A new design of the underground model was developed for this research. In the new design, the UG room was raised aboveground to allow the placement of windows for ventilation and daylight (Figure 4).

(A)

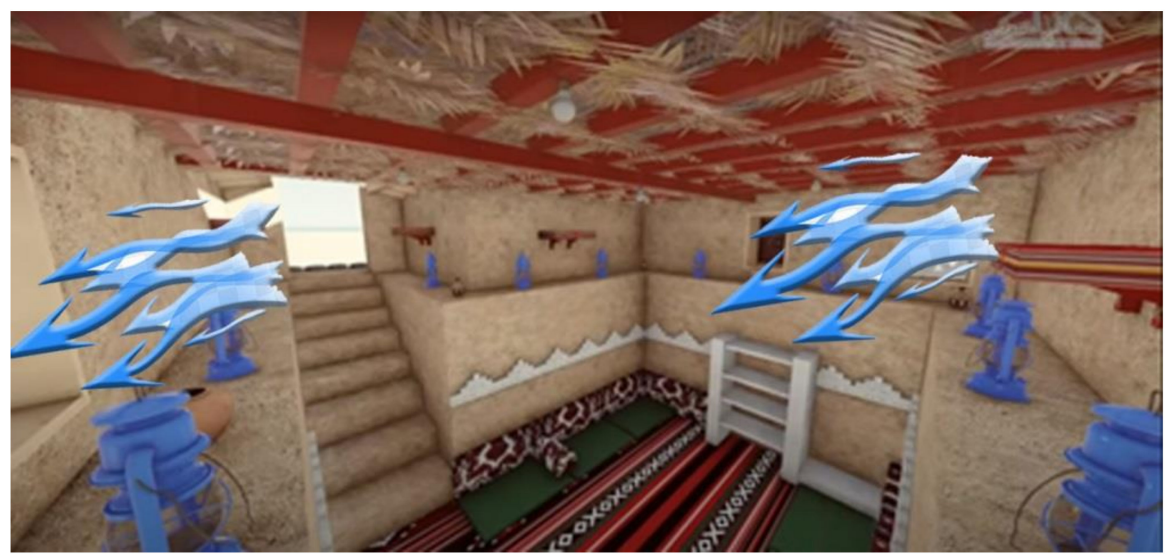

Figure 4. Cont 
(B)

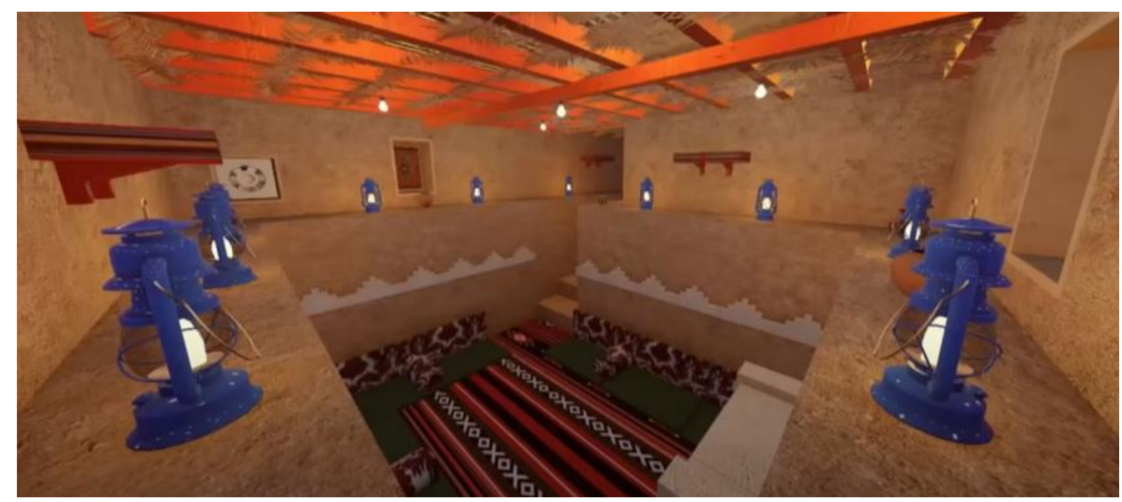

Figure 4. (A) View of actual room model showing the $0.6 \mathrm{~m}$ elevation aboveground level for naturel ventilation, and (B) night view of the room with traditional furniture, designed by Mohammed Al-Amoodi.

\section{Methodology and Materials}

2.1. Design and Construction of Real Model Room Built Underground

This study was conducted using a real constructed model, built in a town called $\mathrm{Al}$ Dwadimi. The dimension of the room was $3.5 \mathrm{~m} \times 4.0 \mathrm{~m}$, with a $1.0 \mathrm{~m}$ elevated atrium for exposing the external wall to the outdoors to allow natural ventilation and daylight. Local and traditional building materials were used in the construction of the model, such as mud and palm fronds (Figure 5). Note that all the examined models were unoccupied.
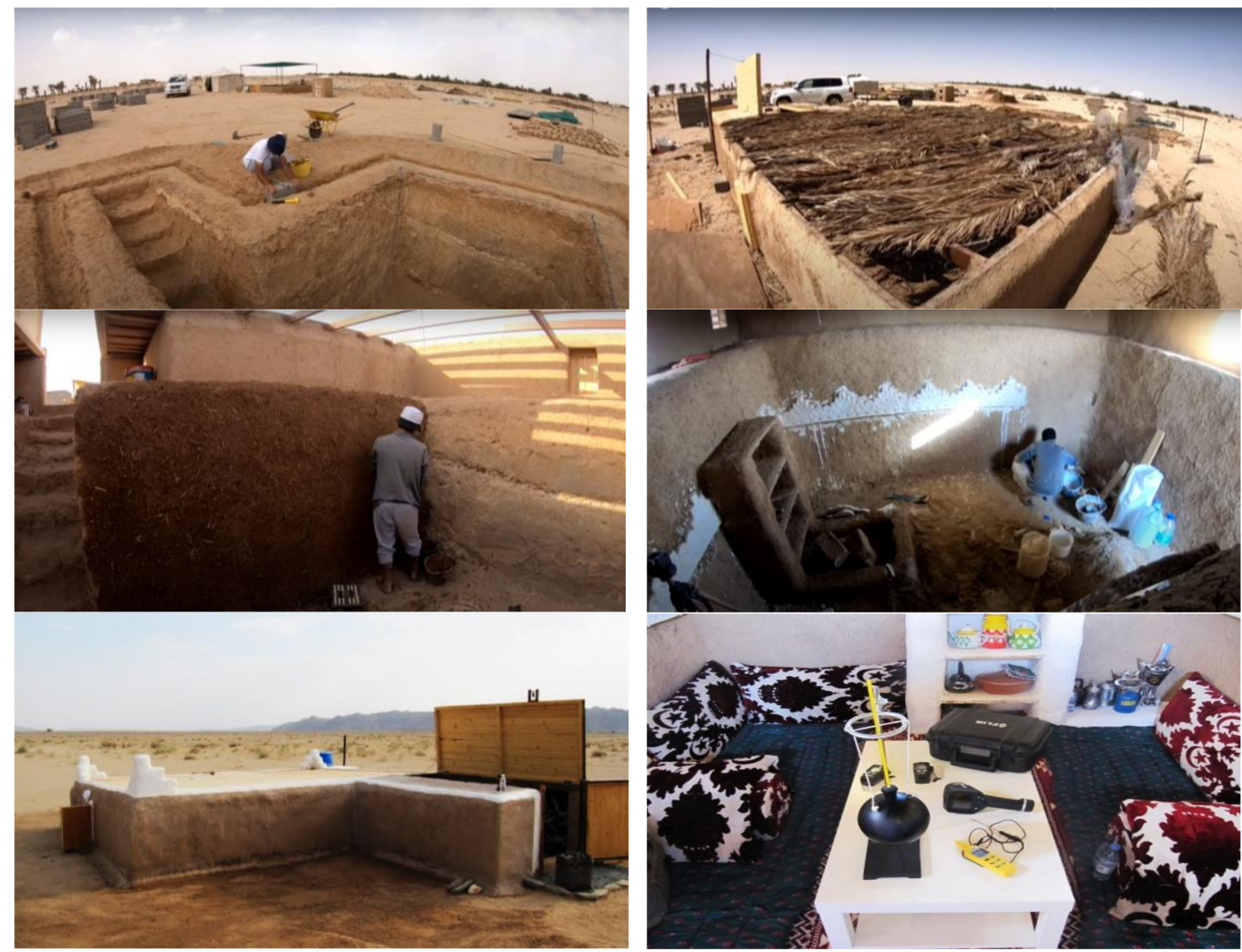

Figure 5. Cont. 


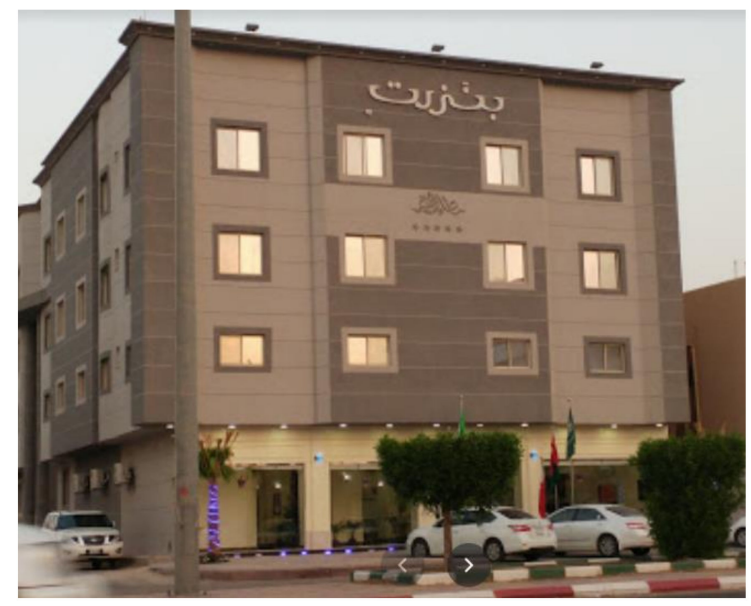

Figure 5. Site construction of underground room from digging to finishing and set-up of the equipment in the underground room; view of the building which has a normal room to compare it with the underground room.

\subsection{Design and Production of Evaporative Cooling Air Conditioning Unit}

The study involved designing and building an on-site evaporative cooling air conditioning unit (ECACU) (Figure 6). The on-site design and building of ECACU provided an affordable approach to create an alternative solution for users; it was a box with the dimension of $80 \mathrm{~cm} \times 80 \mathrm{~cm}$ with a height of $100 \mathrm{~cm}$. There was an internal layer of pads supplied with a watering tube to absorb water and aid in cooling the hot external air. An internal fan was installed to extract air into the indoor room (Table 1).
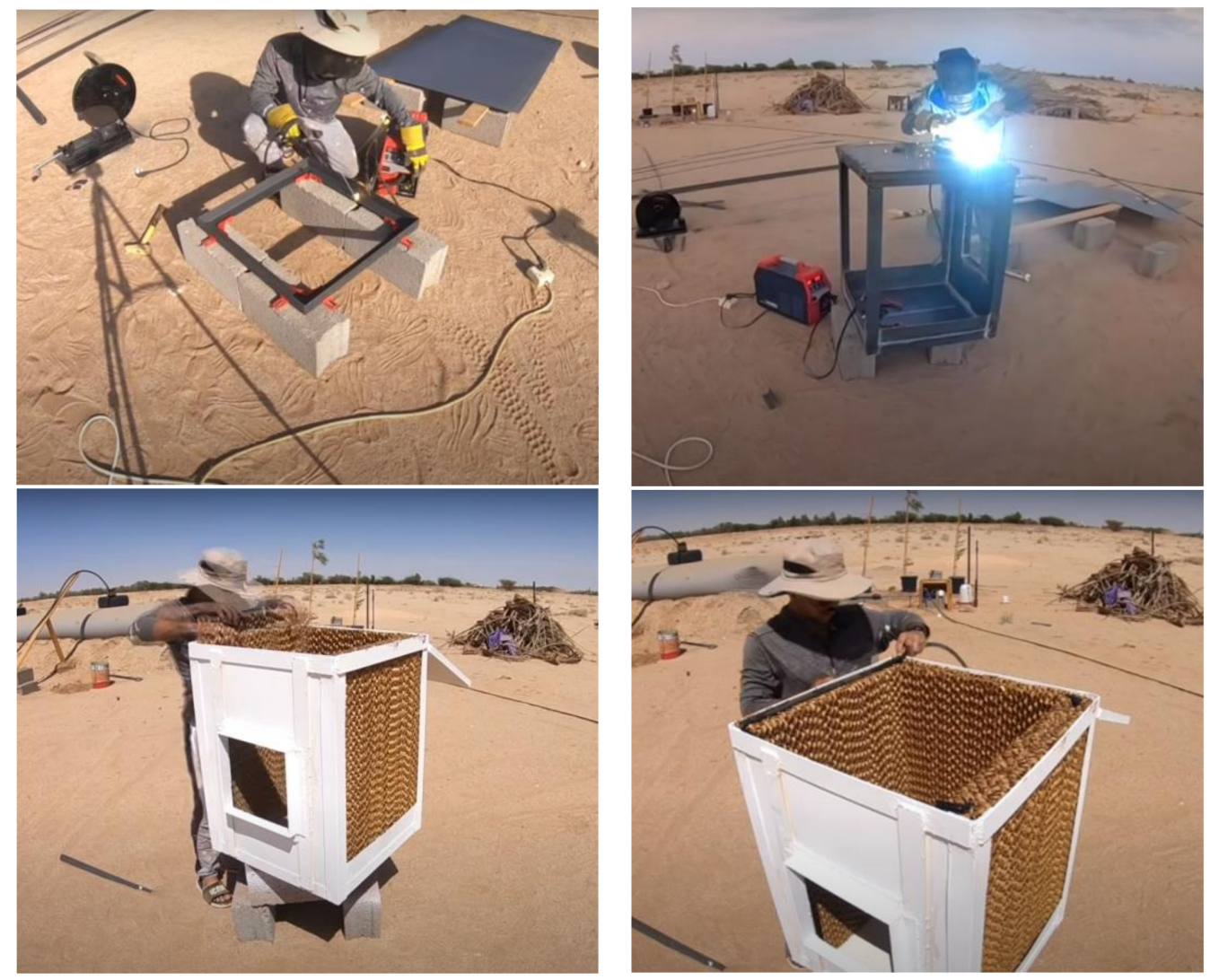

Figure 6. Cont. 


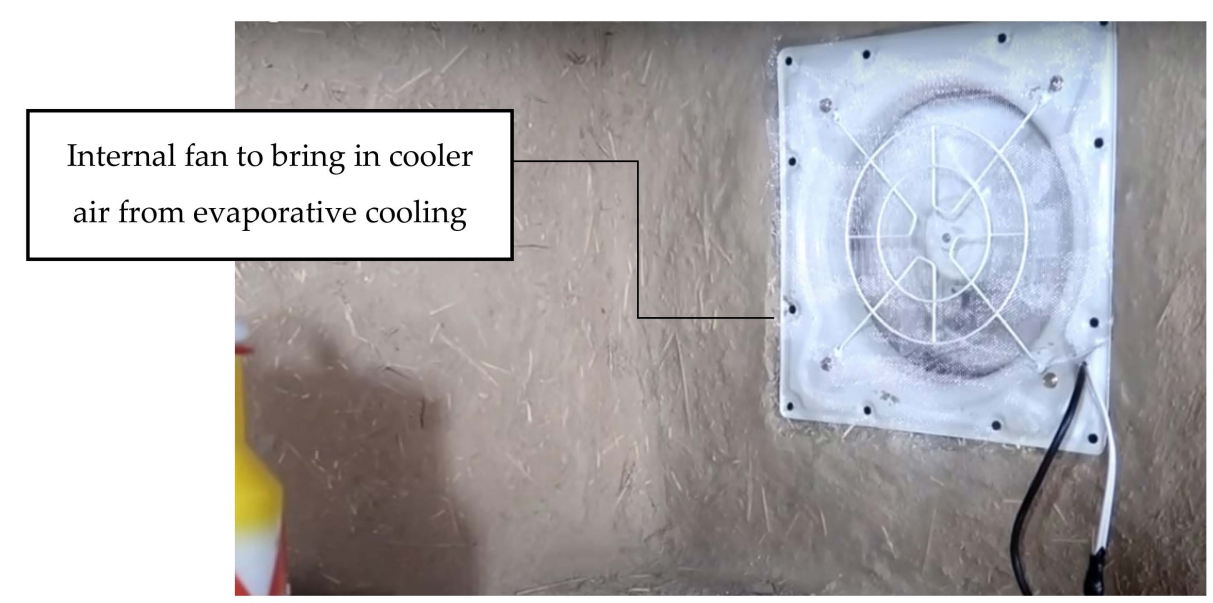

Figure 6. On-site building of evaporative cooling unit with internal fan installed to pull in air from external unit into inside the room.

Table 1. Inner surface temperatures of water tank and internal fan.

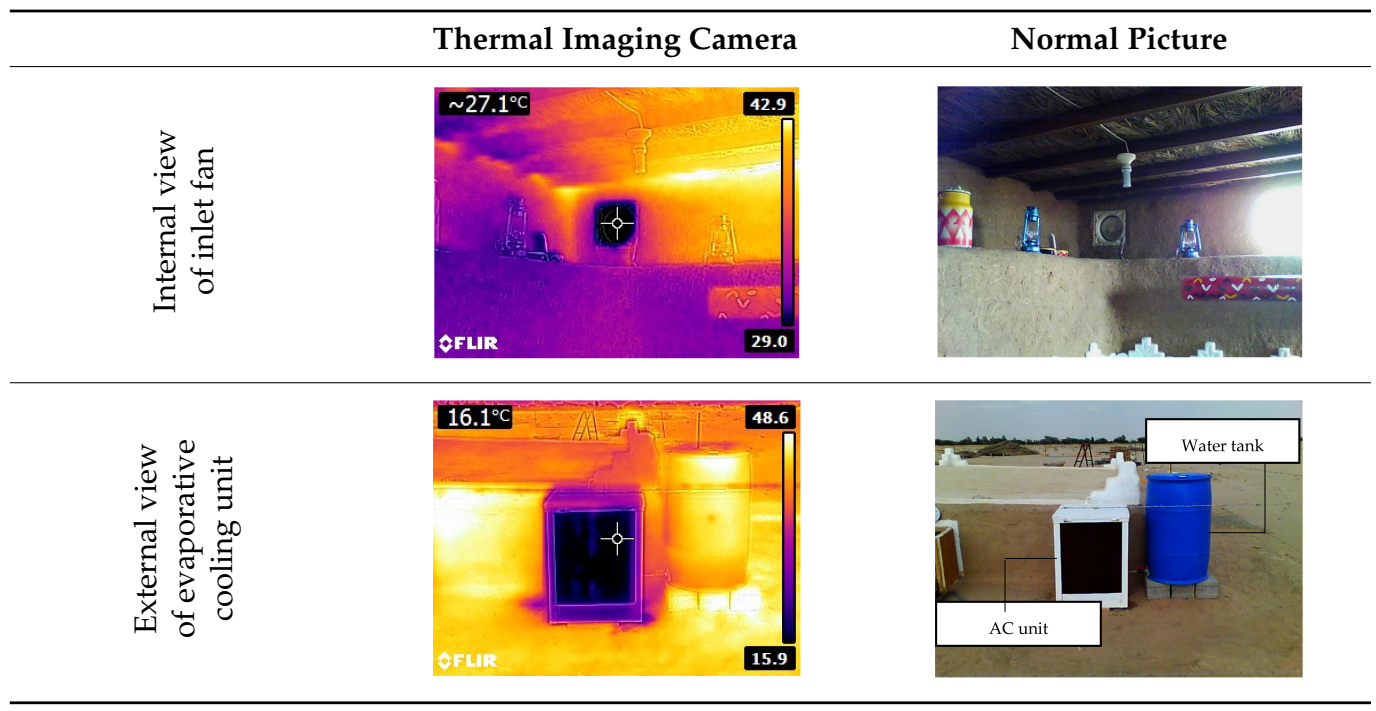

\subsection{Use of Energy Simulation Tool (TAS EDSL)}

In addition to the use of the field measurement of the constructed real model, the computer simulation software TAS EDSL was used to predict some results. This software is used globally in building energy analysis investigations, such as in Chile [55], Austria [56], Singapore [57], Poland [58] Italy [41,42,59,60], Saudi Arabia [61], the UK [45,46,62,63], and Turkey [64].

The model was built with an external wall with a thickness of $35 \mathrm{~cm}$. The conductivity of the wall was $0.82 \mathrm{~W} / \mathrm{mK}$, and the total U-value was $1.45 \mathrm{~W} / \mathrm{m}^{2} \mathrm{~K}$. The room had a top roof made with mud and palm fronds; it had a thickness of $30 \mathrm{~cm}$, conductivity of $1.38 \mathrm{~W} / \mathrm{mK}$, and U-value of $2.09 \mathrm{~W} / \mathrm{m}^{2} \mathrm{~K}$. As the study area consisted of one room, it was divided into one zone within the TAS model. In addition to this, the infiltration of the two windows had the value of 0.5 ach with full operation of natural ventilation.

\subsection{Calibration of Energy Model and Validation}

The research used graphical calibration to verify the adequacy of the results. Figure 6 shows an acceptable agreement between the simulated and the measured results for temperature and humidity, obtained by the use of data loggers. The results indicated acceptable differences, which could be considered minor (Figure 7). In addition, TAS software was validated previously by the author in a study that dealt with a sustainable 
application of an asphalt mixer (RAP). The new design of the building brick could be used in cold regions for thermal insulation capability [65]. The validation used a constructed model in the campus of the University of Taif and compared it with the energy simulated model developed using TAS. As the case study was an underground space, which differed from a normal aboveground space, the validation and calibration were very crucial. Energy software such as TAS EDSL is not usually used to run simulations for underground spaces; however, the current model used a very thick external wall to overcome this issue. This provided a simulation of the underground boundary, which had a very high mass external condition. It is recommended that energy simulation provide more advanced options to test underground spaces. Validation and simulation were carried out using advanced energy tools (Table 2).

(A)
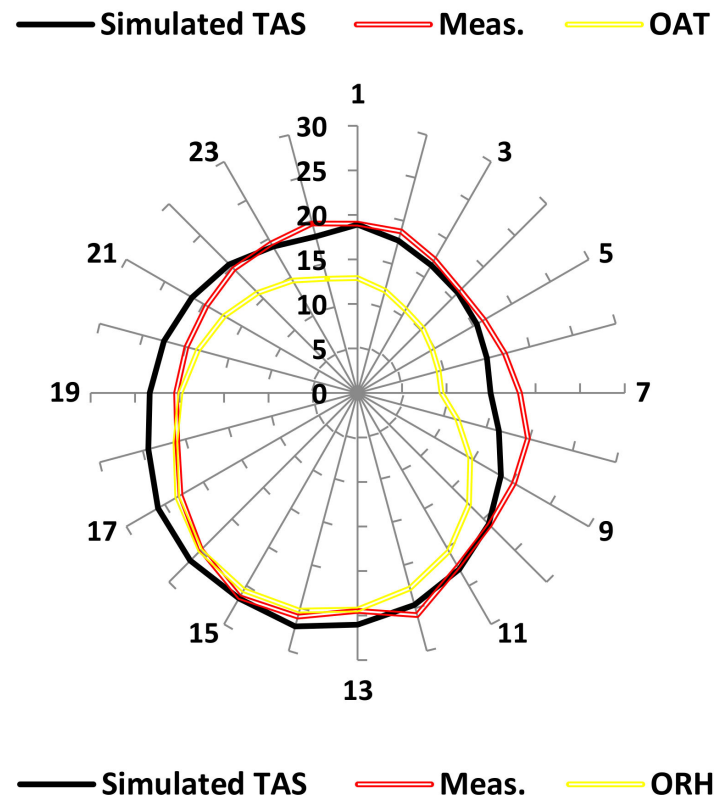

(B)

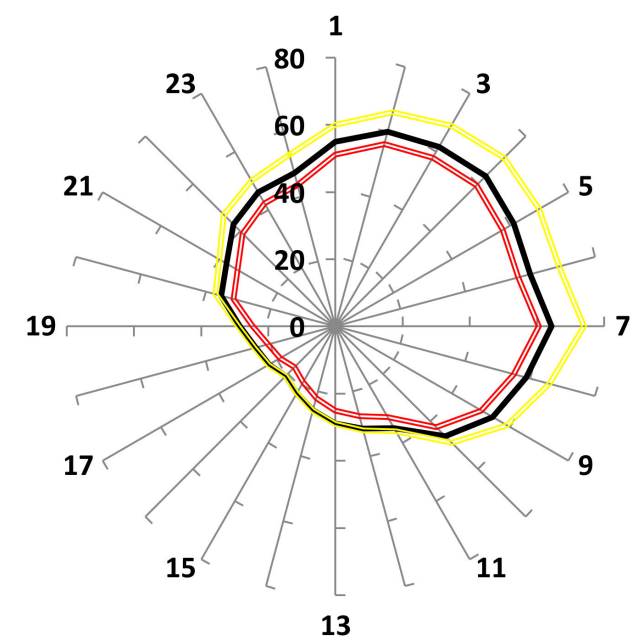

Figure 7. Calibration: (A) indoor temperatures $\left({ }^{\circ} \mathrm{C}\right)$ and $(\mathbf{B})$ relative humidity $(\%)$. 
Table 2. Tools and equipment used in research study.

\begin{tabular}{|c|c|c|c|}
\hline Tool & Image of Tool & Output & Accuracy \\
\hline Thermal imaging camera & & $\begin{array}{l}\text { Temperature measurements range } \\
\text { from }-20 \text { to } 250{ }^{\circ} \mathrm{C}\left(-4 \text { to } 482^{\circ} \mathrm{F}\right)\end{array}$ & $<0.15^{\circ} \mathrm{C}$ \\
\hline $\begin{array}{l}\text { Professional high-temperature } \\
\text { thermometer laser pointer }\end{array}$ & & $\begin{array}{l}\text { Tester gun measuring range }-50 \text { to } \\
\qquad 550^{\circ} \mathrm{C}\end{array}$ & 0.5 to 1.0 \\
\hline $\begin{array}{l}\text { Temperature and humidity } \\
\text { data logger }\end{array}$ & & $\begin{array}{ll}\text { - } & \text { It records } 32,000 \text { data points } \\
\text { - } & \text { Built-in sensor to measure } \\
& \text { temperature and humidity }\end{array}$ & $\begin{array}{c}\text { Temperature: } \pm 1.0^{\circ} \\
\text { Humidity: } \pm 3.0 \%\end{array}$ \\
\hline $\begin{array}{l}\text { TAS EDSL software; Energy } \\
\text { building performance tool }\end{array}$ & EDS & $\begin{array}{l}\text { It considers various energy aspects } \\
\text { such as energy load, solar radiation, } \\
\text { and daylight analysis }\end{array}$ & - \\
\hline
\end{tabular}

\section{Results and Discussion}

The research presented a new design of UGCs enhanced with an on-site built-in evaporative cooling air conditioning unit. Figure 8 shows the indoor temperature and relative humidity of the underground room and the aboveground room, simulated using TAS EDSL for the whole year. The use of UGC helped to maintain a constant fluctuation of temperature as well as relatively high humidity considering the hot and arid climate of Saudi Arabia. From January to March, the average temperature was around $17^{\circ} \mathrm{C}$, which was above the minimum outdoor air temperature by $5^{\circ} \mathrm{C}$. Moreover, the average indoor relative humidity was lower than the outdoor maximum humidity by approximately $33 \%$. This was the power of the TM of the UGC. Figure 9 shows the effect of the TM on the building heat transfer of the underground constructed room compared to the aboveground room. The UGC room had considerably less heat transfer than the aboveground room by as high as $70 \%$. This had a clear influence on the fluctuation of the indoor built environment, particularly temperature, which was linked to thermal comfort. In summer, the UGC room helped to maintain a lower indoor temperature than the maximum outdoor temperature by $3{ }^{\circ} \mathrm{C}$. This was due to under-construction and the lack of an evaporative cooler. Although the climatic classification of this study was hot and arid and the study was carried out during summer, the distinction in humidity was in the range of $45-62 \%$. This was attributed to the natural ventilation consolidated by the utilisation of UGBC. The design of the underground room used a smaller size of glazing for natural ventilation and daylight to control the influence of the solar radiation gain. The research revealed that the use of UGCs in hot climates encouraged with small openings for natural ventilation and daylight could decrease the temperature by $3^{\circ} \mathrm{C}$ (Figures 8 and 9). Figure 9 shows a comparison of the total amount of building heat transfer between the underground room and the aboveground room. The UG room had a very limited fluctuation of building heat transfer, such as conduction, convection, and radiation, while the aboveground room had a 
considerably higher amount of heat transfer. This was attributed to the dramatic swing of the outdoor temperature of the aboveground room as compared to the ground temperature. This resulted in a more comfortable indoor environment of the underground spaces with less reliance on energy use, particularly in extremely hot regions.

Jan

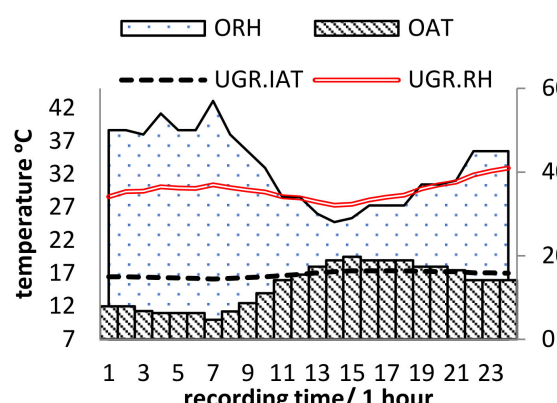

Mar

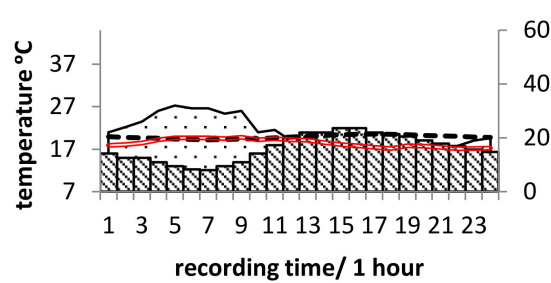

Mar

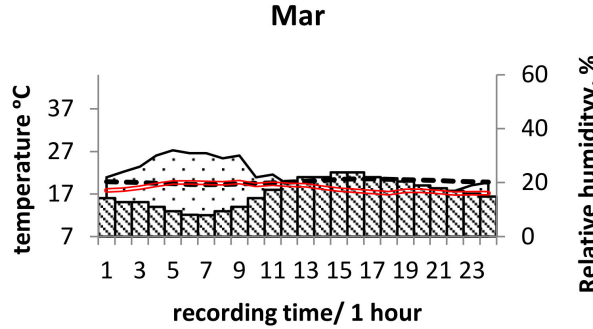

Jul

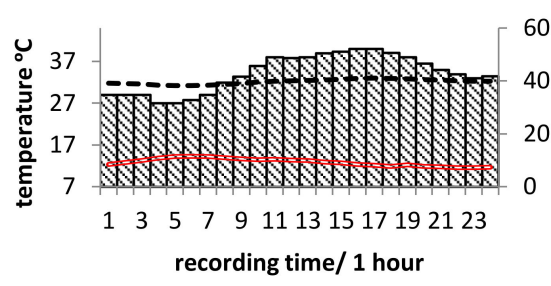

Sep

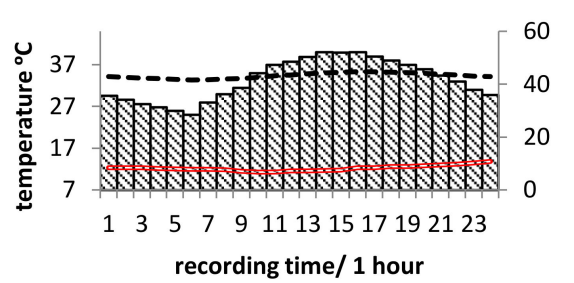

Feb

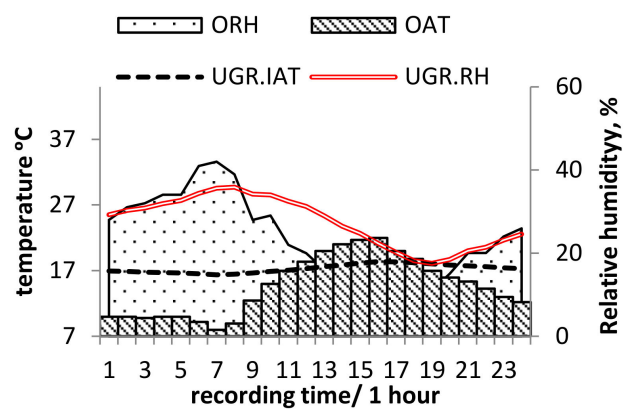

Apr

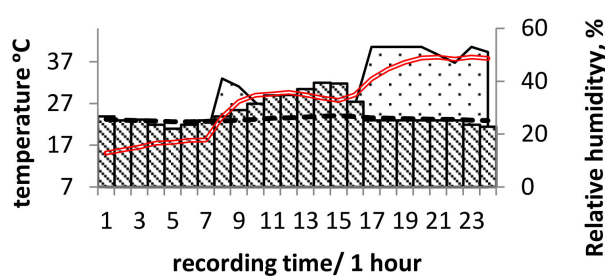

Jun

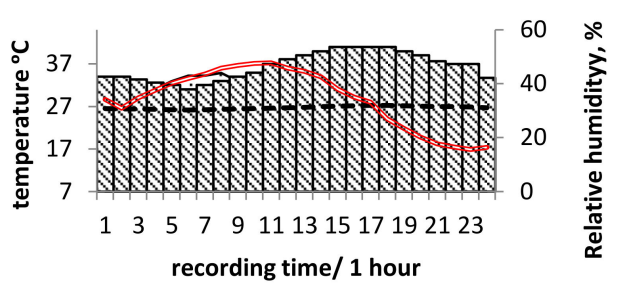

Aug

올

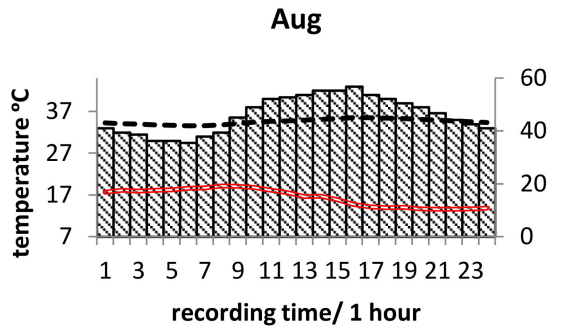

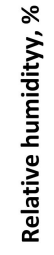

Oct
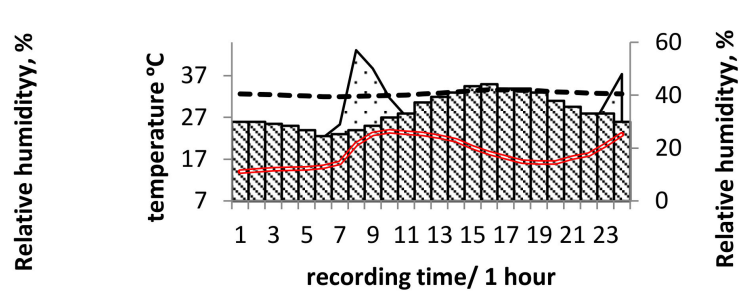



Figure 8. Cont. 

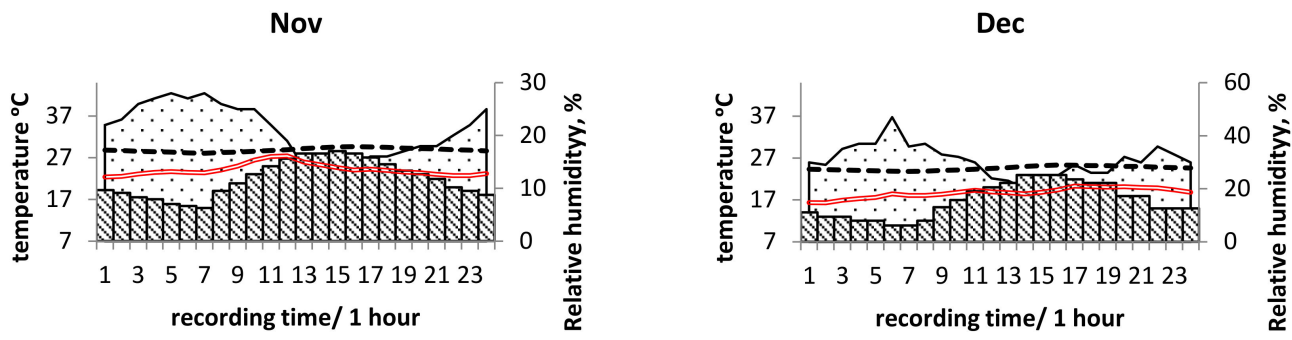

Figure 8. Indoor temperature and relative humidity of underground room and aboveground room, simulated using TAS EDSL for the whole year, where ORH is the outdoor relative humidity, OAT is the outdoor air temperature, UGR.IAT is the underground indoor temperature, and UGR.RH is the underground relative humidity.

(A)

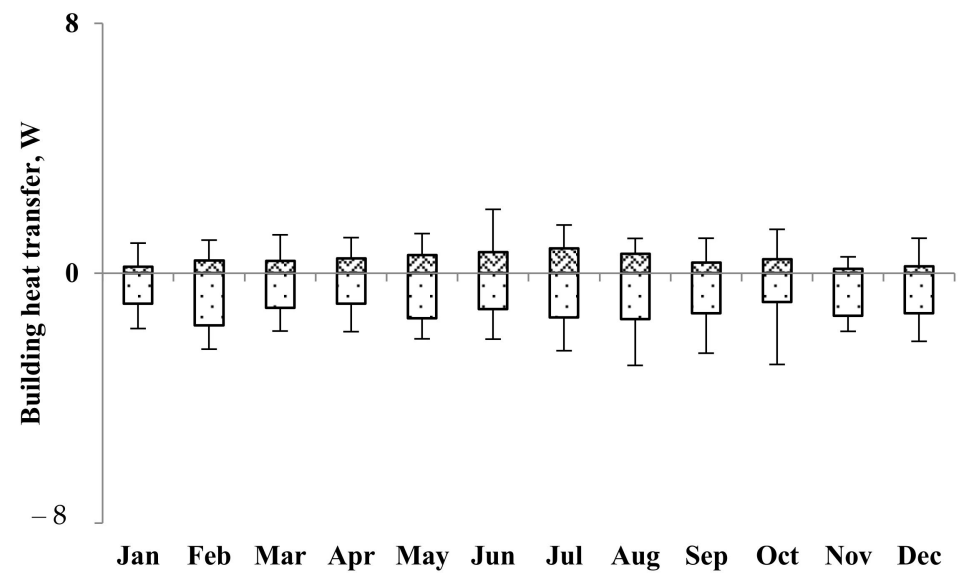

(B)

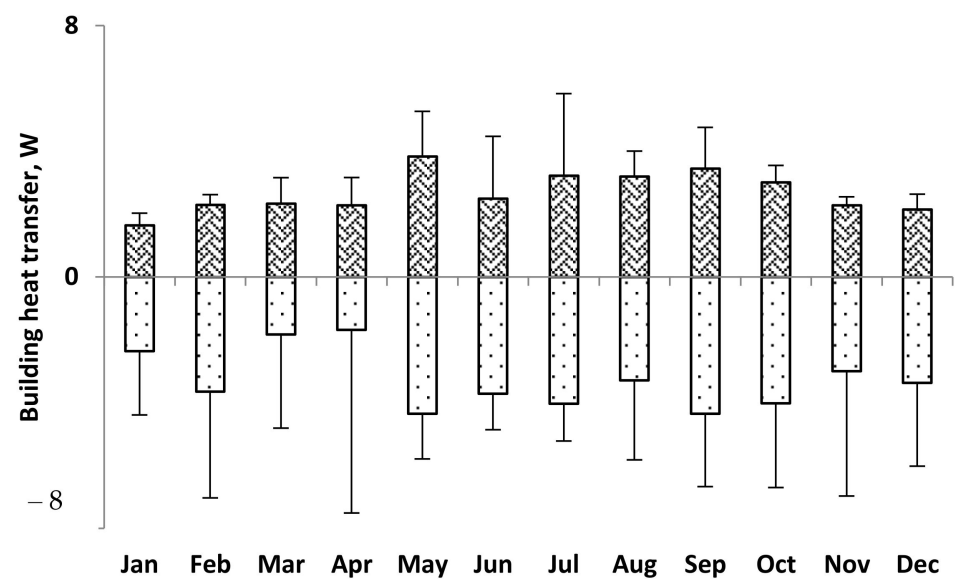

Figure 9. Building heat transfer of (A) underground room and (B) aboveground room.

The room was designed with a small window for natural ventilation and daylight to improve the liveability of UGCs. This is an issue with most recently published research. Although the solar heat gain was primarily affected by the size of the openings and glazing, a minor variation was recorded in different seasons, as shown in Figure 10. There was only a minor variation among all the seasons. As shown in Figure 10, summertime had the highest amount of solar radiation, while wintertime had the lowest with a peak of approximately $100 \mathrm{~W}$. This supported the claim that the window to wall ratio has to be kept to minimum in hot and dry climates [66]. In addition to this, this was similar to the findings of the work of Bulut [67], which investigated the thermal performance of buildings in Australia. The paper revealed that retrofitting windows can contribute to almost $10 \%$ of electricity use. 


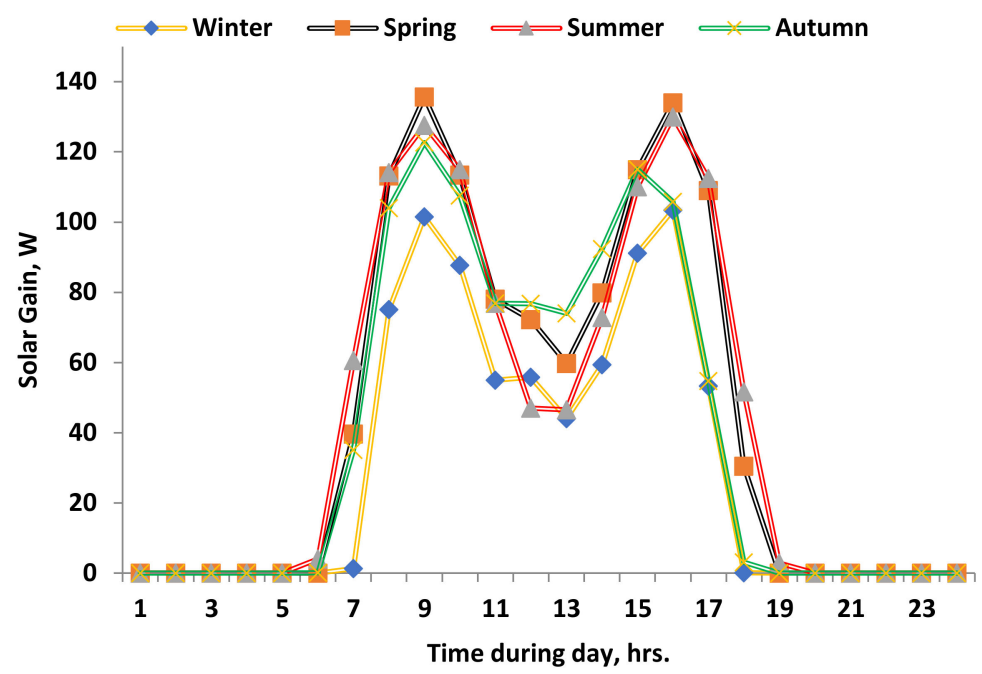

Figure 10. Solar heat gain (SHG) in underground room in all seasons, W.

The study revealed that the use of evaporative cooling could reduce indoor temperatures during the daytime by $12{ }^{\circ} \mathrm{C}$ in summer. This was an enormous reduction, significantly affecting both the comfort level of the users, as well as the energy use (Figure 11). This is quite similar to the work of Rabani [10], which used evaporative cooling and reported a temperature reduction of $7-13^{\circ} \mathrm{C}$. The system also helped to increase the relative humidity by $45 \%$ to be in the range of $40 \%$ to $60 \%$. Such an improvement had a clear effect on the level of thermal comfort of the occupants, and hence, considerably reduced the energy for cooling. The cooling system was found to be very efficient, as shown in Figure 12, which also shows the frequency of decrease in the temperature and increase in the humidity in a $5 \mathrm{~min}$ recording slot. During the first hour, the temperature dropped by $7{ }^{\circ} \mathrm{C}$, and the humidity increased by $13 \%$. This was also linked to the high thermal mass construction of the ground of the underground buildings. This had a clear effect on the total amount of building heat transfer that was exchanged with the building zone in both winter and summer, where in winter, it was found to be warmer than the outdoor temperature, and in summer, it was found to be cooler. This point will hopefully stimulate further research.

(A)

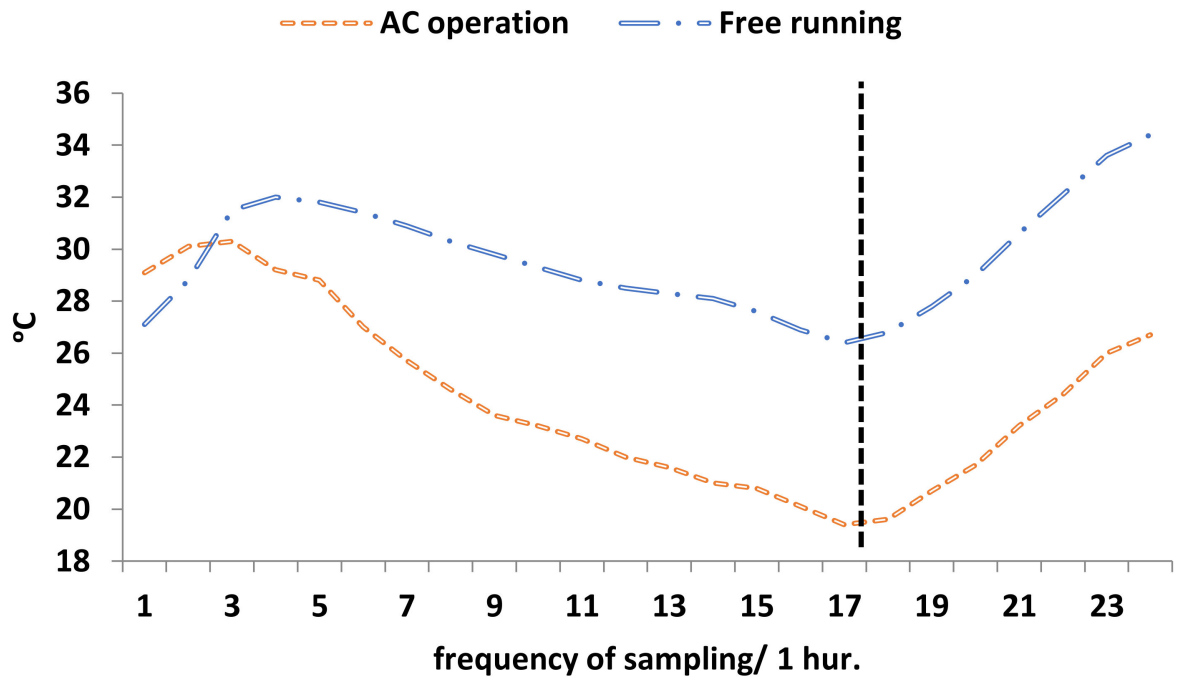

Figure 11. Cont. 


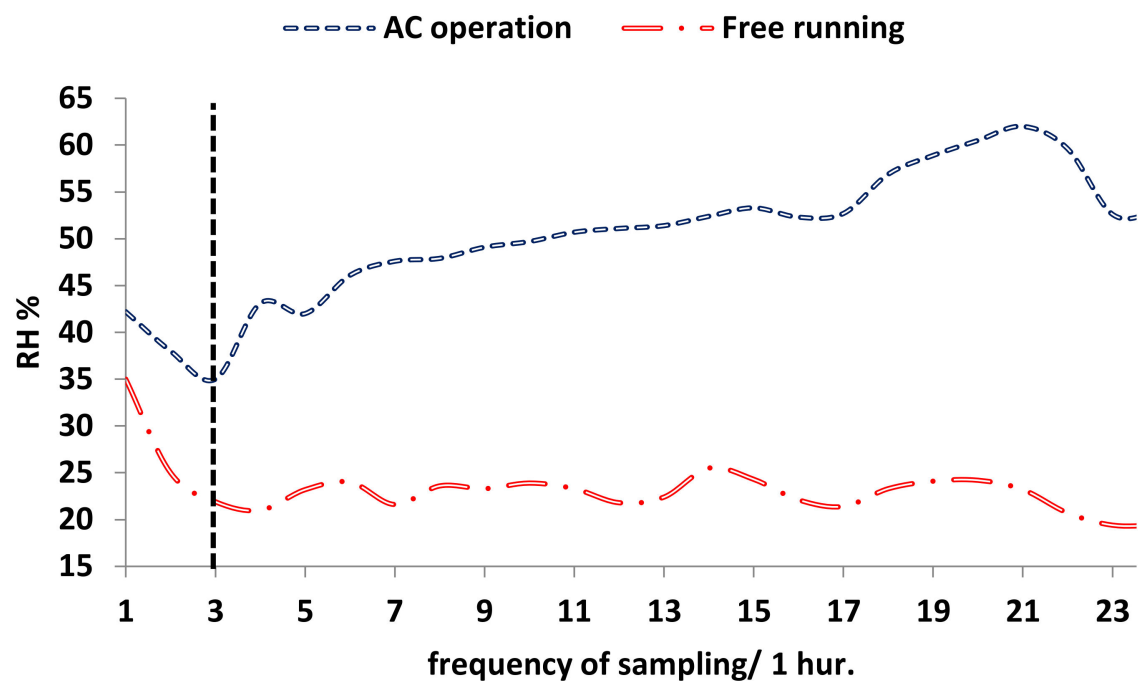

Figure 11. Comparison between (A) indoor air temperature and (B) relative humidity of underground constructed room.

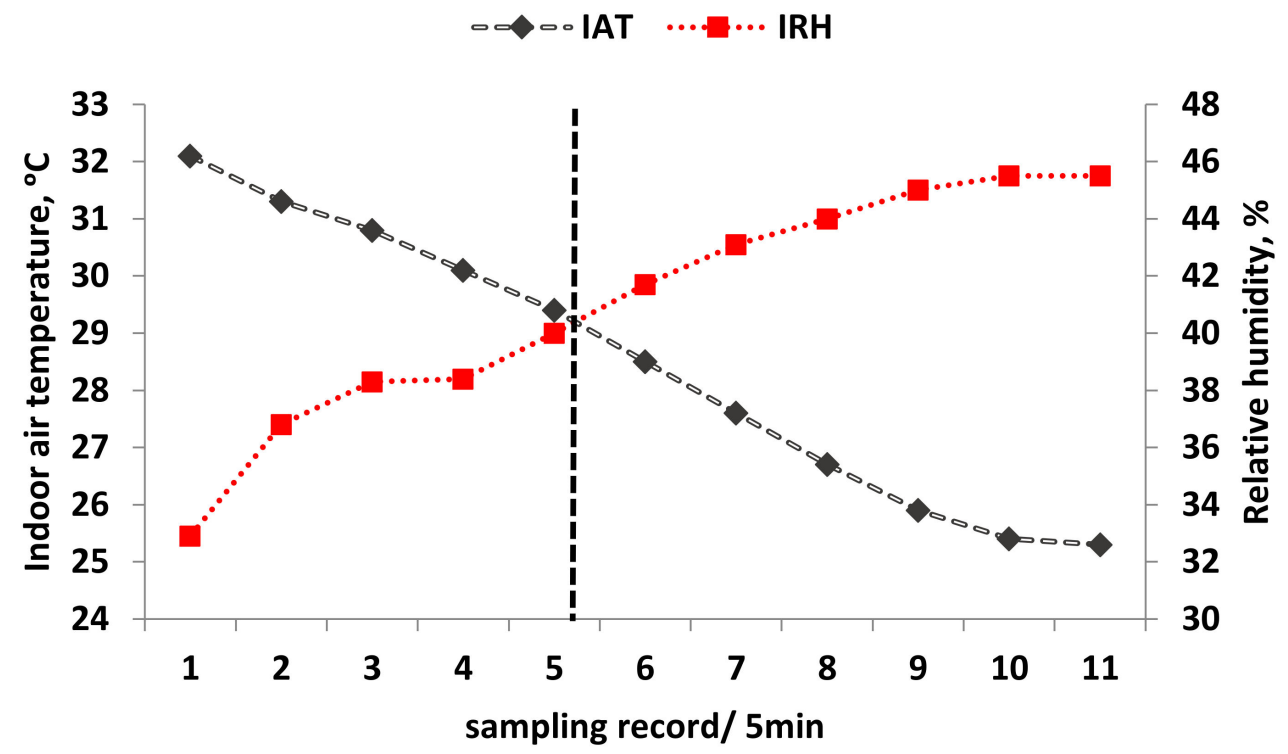

Figure 12. Frequency of reduction in indoor temperature with use of evaporative cooling in sampling record every $5 \mathrm{~min}$, where IAT is indoor air temperature and IRH is indoor relative humidity.

\section{Conclusions}

The current research was carried out in a real underground construction space located in Al-Dwadimi in Saudi Arabia and aimed to analyse the influence of UGCs on indoor air temperature and relative humidity. The new design was elevated aboveground to encourage natural ventilation and daylight. The research used TAS EDSL as the modelling tool, and field measurements were conducted to obtain some measurements. The WWR of the glazing constructed was small to minimise the effect of solar radiation in locations that experience a very harsh outdoor environment, particularly in summer. The research highlighted that the heat transfer in UGCs was twice that of the aboveground spaces. Taking into consideration the issue of the lack of natural ventilation in UGCs, the current built underground space was found to be relatively humid, even though it was summer, and it was a hot and dry region. This could be beneficial in locations that suffer from dryness, particularly during summer. The study also indicated that the use of UGCs in hot climates consolidated with natural ventilation could decrease the indoor air temperature by $3{ }^{\circ} \mathrm{C}$ in summer. This reduction could be as high as $12{ }^{\circ} \mathrm{C}$ upon the utilisation of 
the evaporative cooling technique. The use of evaporative cooling was developed and enhanced with the concept of Mashrabiya, which was an architectural traditional element used in the region. The work would have a great potential in regions with a hot climate, such as in Saudi Arabia where outdoor temperatures soar in both summer and winter. The current study encourages land holders to consider underground spaces in demotic buildings, as they can provide not only extra spaces in the homes but also more comfortable and energy efficient buildings. Based on the current research and findings, it is suggested that further research and investigation be conducted with respect to different shapes and designs of UGCs, as well as structural elements. In addition to this, the behaviour of the occupants can be investigated in relation to the comfort of UGCs.

Funding: Taif University Researchers Supporting Project number (TURSP-2020/196), Taif University, Taif, Saudi Arabia.

Institutional Review Board Statement: Not applicable.

Informed Consent Statement: Not applicable.

Data Availability Statement: The data presented in this study are available on request from the corresponding author.

Acknowledgments: The author acknowledge the support received by Taif University Researchers Supporting Project number (TURSP-2020/196), Taif University, Taif, Saudi Arabia. The Author also would like to thank Abdulla Faiz who constructed the room with the use of basic tools and local materials, and also the interior 3D model which was constructed by Mohammed Al-Amoodi.

Conflicts of Interest: The author declares that he has no conflicts of interest with respect to this paper.

\section{References}

1. Alkaff, S.A.; Sim, S.C.; Efzan, M.N.E. A review of underground building towards thermal energy efficiency and sustainable development. Renew. Sustain. Energy Rev. 2016, 60, 692-713. [CrossRef]

2. Porras-Amores, C.; Mazarrón, F.R.; Cañas, I.; Sáez, P.V. Natural ventilation analysis in an underground construction: CFD simulation and experimental validation. Tunn. Undergr. Space Technol. 2019, 90, 162-173. [CrossRef]

3. Galgaro, A.; Santa, G.D.; Cola, S.; Cultrera, M.; de Carli, M.; Conforti, F.; Scotton, P.; Viesi, D.; Fauri, M. Underground warehouses for food storage in the Dolomites (Eastern alps-Italy) and energy efficiency. Tunn. Undergr. Space Technol. 2020, $102,103411$. [CrossRef]

4. Shi, L.; Zhang, H.; Li, Z.; Luo, Z.; Liu, J. Optimizing the thermal performance of building envelopes for energy saving in underground office buildings in various climates of China. Tunn. Undergr. Space Technol. 2018, 77, 26-35. [CrossRef]

5. Yu, J.; Kang, Y.; Zhai, Z. Advances in research for underground buildings: Energy, thermal comfort and indoor air quality. Energy Build. 2020, 215, 109916. [CrossRef]

6. Jomehzadeha, F.; Nejata, P.; Calautitc, J.K.; Yusofa, M.B.M.; Zakid, S.A.; Hughesc, B.R.; Yazid, M.N.A.W.M. A review on windcatcher for passive cooling and natural ventilation in buildings, Part 1: Indoor air quality and thermal comfort assessment. Renew. Sustain. Energy Rev. 2017, 70, 736-756. [CrossRef]

7. Mohammadshahi, S.; Tavakoli, M.R.; Samsam-Khayani, H.; Nili-Ahmadabadi, M.; Kim, K.C. Investigation of naturally ventilated shavadoons component: Architectural underground pattern on ventilation. Tunn. Undergr. Space Technol. 2019, 91, 102990. [CrossRef]

8. Andolsun, S.; Culp, C.H.; Haberl, J.; Witte, M.J. EnergyPlus vs. DOE-2.1e: The effect of ground-coupling on energy use of a code house with basement in a hot-humid climate. Energy Build. 2011, 43, 1663-1675. [CrossRef]

9. Casals, M.; Gangolells, M.; Forcada, N.; Macarulla, M.; Giretti, A. A breakdown of energy consumption in an underground station. Energy Build. 2014, 78, 89-97. [CrossRef]

10. Rabani, M. Performance analysis of a passive cooling system equipped with a new designed solar chimney and a water spraying system in an underground channel. Sustain. Energy Technol. Assess. 2019, 35, 204-219. [CrossRef]

11. Alwetaishi, M.; Balabel, A.; Abdelhafiz, A.; Issa, U.; Sharaky, I.; Shamseldin, A.; Al-Surf, M.; Al-Harthi, M.; Gadi, M. User thermal comfort in historic buildings: Evaluation of the potential of thermal mass, orientation, evaporative cooling and ventilation. Sustainability 2020, 12, 9672. [CrossRef]

12. Da Veiga, A.P.; Güths, S.; da Silva, A.K. Evaporative cooling in building roofs: Local parametric and global analyses (Part-2). Sol. Energy 2020, 207, 1009-1020. [CrossRef]

13. Bagasi, A.A.; Calautit, J.K. Experimental field study of the integration of passive and evaporative cooling techniques with Mashrabiya in hot climates. Energy Build. 2020, 225, 110325. [CrossRef] 
14. Trepci, E.; Maghelal, P.; Azar, E. Urban built context as a passive cooling strategy for buildings in hot climate. Energy Build. 2021, 231, 110606. [CrossRef]

15. Tewari, P.; Mathur, S.; Mathur, J.; Kumar, S.; Loftness, V. Field study on indoor thermal comfort of office buildings using evaporative cooling in the composite climate of India. Energy Build. 2019, 199, 145-163. [CrossRef]

16. Tewari, P.; Mathur, S.; Mathur, J.; Loftness, V.A. Abdul-Aziz, Advancing building bioclimatic design charts for the use of evaporative cooling in the composite climate of India. Energy Build. 2019, 184, 177-192. [CrossRef]

17. Sotelo-Salas, C.; del Pozo, C.E.; Esparza-López, C.J. Thermal assessment of spray evaporative cooling in opaque double skin facade for cooling load reduction in hot arid climate. J. Build. Eng. 2021, 38, 102156. [CrossRef]

18. Kowalski, P.; Kwiecień, D. Evaluation of simple evaporative cooling systems in an industrial building in Poland. J. Build. Eng. 2020, 32, 101555. [CrossRef]

19. Saif, J.; Wright, A.; Khattak, S.; Elfadli, K. Keeping Cool in the Desert: Using Wind Catchers for Improved Thermal Comfort and Indoor Air Quality at Half the Energy. Buildings 2021, 11, 100. [CrossRef]

20. Ghoulem, M.; el Moueddeb, K.; Nehdi, E.; Zhong, F.; Calautit, J. Design of a passive downdraught evaporative cooling windcatcher (PDEC-WC) system for greenhouses in hot climates. Energies 2020, 13, 2934. [CrossRef]

21. Ghoulem, M.; El Moueddeb, K.; Nehdi, E.; Zhong, F.; Calautit, J. Analysis of passive downdraught evaporative cooling windcatcher for greenhouses in hot climatic conditions: Parametric study and impact of neighbouring structures. Biosyst. Eng. 2020, 197, 105-121. [CrossRef]

22. Choi, H.-H.; Cho, H.-N.; Seo, J.W. Risk Assessment Methodology for Underground Construction Projects. J. Constr. Eng. Manag. 2004, 130, 258-272. [CrossRef]

23. Working, I.T.A.; Number, G. Underground or aboveground? Making the choice for urban mass transit systems. Tunn. Undergr. Space Technol. 2004, 19, 3-28. [CrossRef]

24. Alaidroos, A.; Krarti, M. Experimental validation of a numerical model for ventilated wall cavity with spray evaporative cooling systems for hot and dry climates. Energy Build. 2016, 131, 207-222. [CrossRef]

25. Qihu, Q. Present state, problems and development trends of urban underground space in China. Tunn. Undergr. Space Technol. 2016, 55, 280-289. [CrossRef]

26. Tengborg, P.; Sturk, R. Development of the use of underground space in Sweden. Tunn. Undergr. Space Technol. 2016, 55, 339-341. [CrossRef]

27. Vähäaho, I. An introduction to the development for urban underground space in Helsinki. Tunn. Undergr. Space Technol. 2016, 55, 324-328. [CrossRef]

28. Wallace, M.I.; Ng, K.C. Development and application of underground space use in Hong Kong. Tunn. Undergr. Space Technol. 2016, 55, 257-279. [CrossRef]

29. Zhao, J.; Künzli, O. An introduction to connectivity concept and an example of physical connectivity evaluation for underground space. Tunn. Undergr. Space Technol. 2016, 55, 205-213. [CrossRef]

30. Nang, E.E.K.; Abuduxike, G.; Posadzki, P.; Divakar, U.; Visvalingam, N.; Nazeha, N.; Dunleavy, G.; Christopoulos, G.I.; Soh, C.K.; Jarbrink, K.; et al. Review of the potential health effects of light and environmental exposures in underground workplaces. Tunn. Undergr. Space Technol. 2019, 84, 201-209. [CrossRef]

31. Tan, Z.; Roberts, A.C.; Lee, E.H.; Kwok, K.W.; Car, J.; Soh, C.K.; Christopoulos, G. Transitional areas affect perception of workspaces and employee well-being: A study of underground and above-ground workspaces. Build. Environ. 2020, 179, 106840. [CrossRef]

32. Shan, M.; Hwang, B.g.; Wong, K.S.N. A preliminary investigation of underground residential buildings: Advantages, disadvantages, and critical risks. Tunn. Undergr. Space Technol. 2017, 70, 19-29. [CrossRef]

33. Roy, R. Earth-Sheltered Houses: How to Build an Affordable Underground Home; New Society Publisher: Gabriola, BC, Canada, 2006.

34. Mazarron, F.R.; Canas, I. Exponential sinusoidal model for predicting temperature inside underground wine cellars from a Spanish region. Energy Build. 2008, 40, 1931-1940. [CrossRef]

35. Krarti, M. Effect of spatial variation of soil thermal properties on slab-on-ground heat transfer. Build. Environ. 1996, 31, 51-57. [CrossRef]

36. Li, G.S.N.; Chen, F.; Xu, B. Theoretical modeling framework for an unsaturated freezing soil. Cold Reg. Sci. Technol. 2008, 54, 19-35. [CrossRef]

37. Yu, S.; Yu, Z.; Liu, P.; Feng, G. Influence of environmental factors on wall mold in underground buildings in Shenyang City, China. Sustain. Cities Soc. 2019, 46, 101452. [CrossRef]

38. Kim, J.; Cha, S.H.; Koo, C.; Tang, S.k. The effects of indoor plants and artificial windows in an underground environment. Build. Environ. 2018, 138, 53-62. [CrossRef]

39. Li, Y.; Yam, J.C.W. Designing Thermal Mass in Naturally Ventilated Buildings. Int. J. Vent. 2004, 2, 313-324. [CrossRef]

40. Wolisz, H.; Kull, T.M.; Müller, D.; Kurnitski, J. Self-learning model predictive control for dynamic activation of structural thermal mass in residential buildings. Energy Build. 2020, 207, 109542. [CrossRef]

41. Shan, K.; Wang, J.; Hu, M.; Gao, D. A model-based control strategy to recover cooling energy from thermal mass in commercial buildings. Energy 2019, 172, 958-967. [CrossRef]

42. Ghoreishi, A.H.; Ali, M.M. Parametric study of thermal mass property of concrete buildings in US climate zones. Archit. Rev. 2013, 56, 103-117. [CrossRef] 
43. Csáky, I.; Kalmár, F. Investigation of the relationship between the allowable transparent area, thermal mass and air change rate in buildings. J. Build. Eng. 2017, 12, 1-7. [CrossRef]

44. Shaafigh, P.; Asadi, I.; Mahyuddin, N.B. Concrete as a thermal mass material for building applications-A review. J. Build. Eng. 2018, 19, 14-25. [CrossRef]

45. Reilly, A.; Kinnane, O. The impact of thermal mass on building energy consumption. Appl. Energy 2017, 198, 108-121. [CrossRef]

46. Albayyaa, H.; Hagare, D.; Saha, S. Energy conservation in residential buildings by incorporating Passive Solar and Energy Efficiency Design Strategies and higher thermal mass. Energy Build. 2019, 182, 205-213. [CrossRef]

47. Rodrigues, E.; Fernandes, M.S.; Gaspar, A.R.; Gomes, Á.; Costa, J.J. Thermal transmittance effect on energy consumption of Mediterranean buildings with different thermal mass. Appl. Energy 2019, 252, 113437. [CrossRef]

48. Kumar, S.; Tewari, P.; Mathur, S.; Mathur, J. Development of mathematical correlations for indoor temperature from field observations of the performance of high thermal mass buildings in India. Build. Environ. 2017, 122, 324-342. [CrossRef]

49. Yousef, W.A.; Lang, W.; Yousef, W.A. Simulations and quantitative data analytic interpretations of indoor-outdoor temperatures in a high thermal mass structure. J. Build. Eng. 2017, 12, 68-76. [CrossRef]

50. Perini, K. Retrofitting with vegetation recent building heritage applying a design tool—the case study of a school building. Front. Archit. Res. 2013, 2, 267-277. [CrossRef]

51. Jiao, J.; Xia, Q.; Shi, F. Nondestructive inspection of a brick e timber structure in a modern architectural heritage building: Lecture hall of the Anyuan Miners' Club, China. Front. Archit. Res. 2019, 8, 348-358. [CrossRef]

52. Kumar, S.; Singh, M.K.; Mathur, A.; Mathur, S.; Mathur, J. Thermal performance and comfort potential estimation in low-rise high thermal mass naturally ventilated office buildings in India: An experimental study. J. Build. Eng. 2018, 20, 569-584. [CrossRef]

53. Deng, J.; Yao, R.; Yu, W.; Zhang, Q.; Li, B. Effectiveness of the thermal mass of external walls on residential buildings for part-time part-space heating and cooling using the state-space method. Energy Build. 2019, 190, 155-171. [CrossRef]

54. Meteonorm, Weather file of Al-Dwadimi Town. 2019. Available online: https://meteonorm.com/ (accessed on 19 December 2020).

55. Pino, A.; Bustamante, W.; Escobar, R.; Pino, F.E. Thermal and lighting behavior of office buildings in Santiago of Chile. Energy Build. 2012, 47, 441-449. [CrossRef]

56. Berger, T.; Amann, C.; Formayer, H.; Korjenic, A.; Pospichal, B.; Neururer, C.; Smutny, R. Impacts of external insulation and reduced internal heat loads upon energy demand of offices in the context of climate change in Vienna, Austria. J. Build. Eng. 2016, 5, 86-95. [CrossRef]

57. Priyadarsini, R.; Hien, W.N.; David, C.K.W. Microclimatic modeling of the urban thermal environment of Singapore to mitigate urban heat island. Sol. Energy 2008, 82, 727-745. [CrossRef]

58. Dudkiewicz, E.; Fidorów-Kaprawy, N. The energy analysis of a hybrid hot tap water preparation system based on renewable and waste sources. Energy 2017, 127, 198-208. [CrossRef]

59. Resuli, P.; Dervishi, S. Thermal performance of cultural heritage Italian housing in Albania. Energy Procedia 2015, 78, 753-758 [CrossRef]

60. Carlini, M.; Zilli, D.; Allegrini, E. Simulating building thermal behaviour: The case study of the School of the State Forestry Corp. Energy Procedia 2015, 81, 55-63. [CrossRef]

61. Alwetaishi, M. Impact of glazing to wall ratio in various climatic regions: A case study, J. King Saud Univ. Eng. Sci. 2019, 31, 6-18. [CrossRef]

62. Kendrick, C.; Ogden, R.; Wang, X.; Baiche, B. Thermal mass in new build UK housing: A comparison of structural systems in a future weather scenario. Energy Build. 2012, 48, 40-49. [CrossRef]

63. Zoras, S.; Veranoudis, S.; Dimoudi, A. Micro- climate adaptation of whole building energy simulation in large complexes. Energy Build. 2017, 150, 81-89. [CrossRef]

64. Gucyeter, B. Evaluating diverse patterns of occupant behavior regarding control-based activities in energy performance simulation. Front. Archit. Res. 2018, 7, 167-179. [CrossRef]

65. Alwetaishi, M.; Kamel, M.; Al-Bustami, N. Sustainable applications of asphalt mixes with reclaimed asphalt pavement (RAP) materials: Innovative and new building brick. Int. J. Low-Carbon Technol. 2019, 14, 364-374. [CrossRef]

66. Alwetaishi, M.; Benjeddou, O. Impact of Window to Wall Ratio on Energy Loads in Hot Regions: A Study of Building Energy Performance. Energies 2021, 14, 1080. [CrossRef]

67. Bulut, M.; Wilkinson, S.; Khan, A.; Jin, X.; Lee, C. Thermal performance of retrofitted secondary glazed windows in residential buildings-Two cases from Australia. Smart Sustain. Built Environ. 2021. [CrossRef] 